\title{
Kontrola prac spawalniczych na przykładzie elementów elektrowni wiatrowej
}

\section{Control of welding works on the example of a wind tower production}

\section{Streszczenie}

W artykule przedstawiono zagadnienia związane z przygotowaniem produkcji i kontrolą jakości dla konstrukcji wież wiatrowych. Omówiono zakres kontroli i problemy, jakie pojawiły się w trakcie realizacji zlecenia.

Słowa kluczowe: kontrola prac; przygotowanie prac; wymagania; personel spawalniczy; konstrukcja offshorowa
\end{abstract}

Wstęp

Latem i jesienią 2017 firma Gotech Oddział Dolna Odra wykonała serię czterdziestu elementów morskich wież wiatrowych. Autor, pracując przy tym projekcie jako inspektor, nadzorował wykonywane prace spawalnicze. Niniejszy artykuł jest podsumowaniem doświadczeń i obserwacji poczynionych przy tym projekcie.

\section{Opis konstrukcji}

Nadzorowana konstrukcja to stalowe podstawy morskiej wieży wiatrowej z elementami osprzętu. Wykonane z rury o średnicy $1680 \mathrm{~mm}$, długości ok. $10 \mathrm{~m}$. Grubość ścianki $60 \div 75 \mathrm{~mm}$. Do rury spawano kołnierz grubości $75 \mathrm{~mm}$, odgałęzienia rur grubości $35 \mathrm{~mm}$, oraz elementy mocujące osprzęt. Elementy te w postaci węzłówek, uchwytów etc. miały grubość w przedziale $15 \div 60 \mathrm{~mm}$. Połączenia spawane wykonano przeważnie jako złącza kątowe ze spoinami czołowymi. Rysunek 1 przedstawia gotową kolumnę, rysunki 2 i 3 - oznaczenie spoin, rysunek 4 - opis spoiny, a rysunek 5 - status badań NDT.

\section{Wymagania}

Wymagania dotyczące wykonania i kontroli prac spawalniczych klient opracował w oparciu o przepisy morskiego towarzystwa klasyfikacyjnego DNV: DNV-OS-C401 [1,5] i EN 3834-2 [2]. Podobne wymagania są opisane w opracowaniu [3,4].

Materiał podstawowy: S $355 \mathrm{~J} 2$, dostawa obrobionych elementów przez zamawiającego.

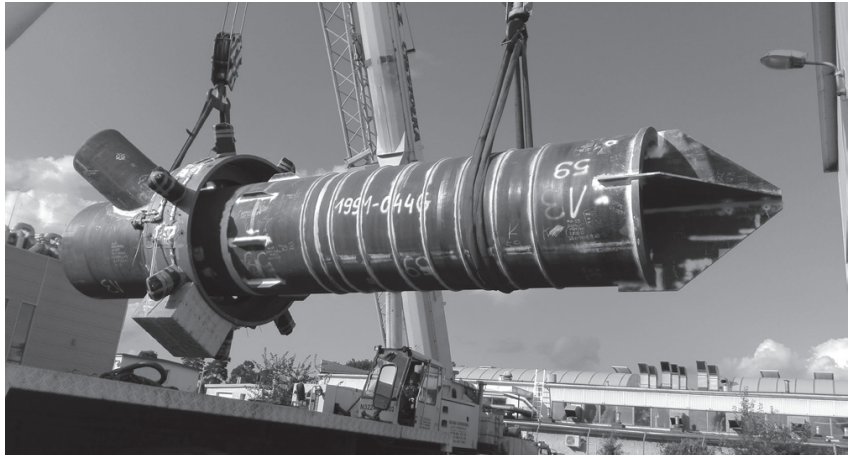

Rys. 1. Gotowa kolumna

Fig. 1. The PIN is ready

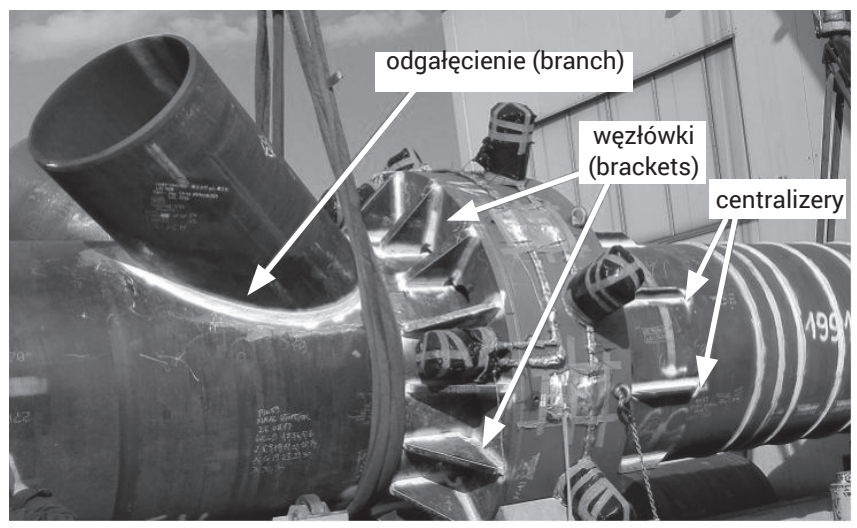

Rys. 2. Usytuowanie spoin na konstrukcji

Fig. 2. The main welding joints on the structure

Mgr inż. Jacek Saperski - Biuro Techniczne.

Autor korespondencyjny/Corresponding author: jsaperski@op.pl 


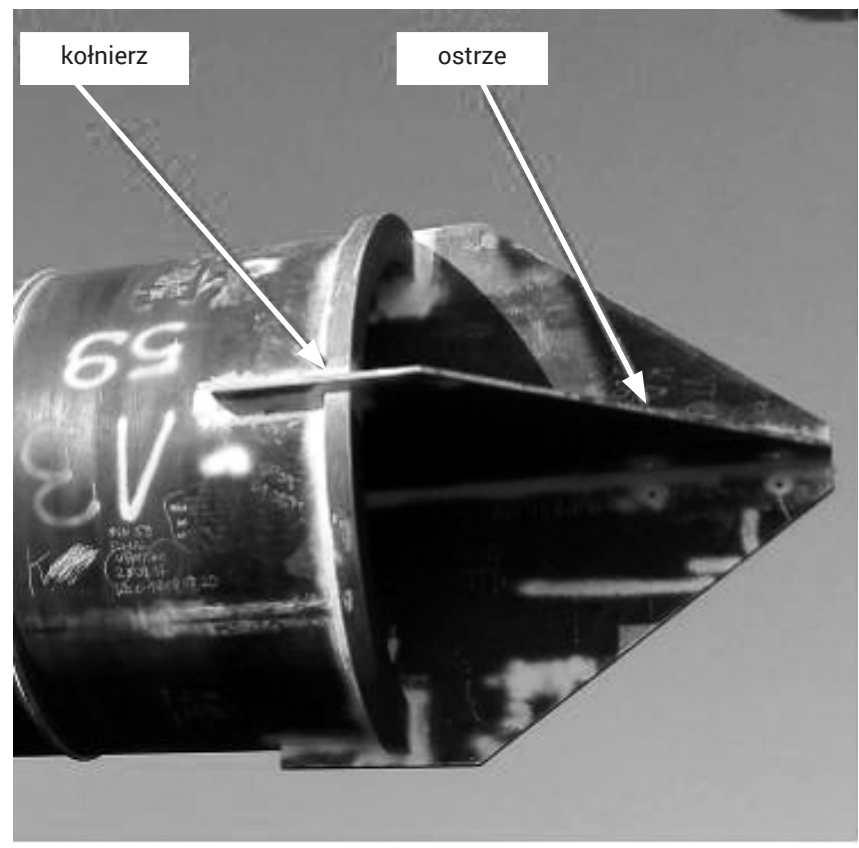

Rys. 3. Usytuowanie spoin na konstrukcji

Fig. 3. The main welding joints on the structure

Poziom jakości dla spoin i zakres badań podano w tablicy I. Końcowe badania NDT prowadzano min. 24 h po zakończenia prac spawalniczych.

\section{Przygotowanie produkcji}

\section{Spawacze}

Dopuszczenie spawaczy dokonywano na podstawie:

- właściwych uprawnień zgodnie z PN-EN ISO 9606-1,

- pomyślnego zaliczenia testu sprawdzającego.

Spawacze wykonywali spoinę czołową na złączu teowym. Blacha $\mathrm{t}=40 \mathrm{~mm}$, ukosowanie na K. Zakres badania złącza: VT, UT, kryterium akceptacji: poziom B wg PN-EN 5817.

Spawacze, którzy zostali dopuszczeni do pracy, przechodzili szkolenie, w ramach którego byli zapoznawani z dokumentacją spawalniczą, instrukcjami WPS, wymaganiami dotyczącymi opisu spoin. Rozpoczynali pracę od najprostszych spoin, stopniowo przechodząc do spoin bardziej wymagających.

\section{Personel kontroli prac spawalniczych}

Kontrole prac spawalniczych na bieżąco prowadzili inspektorzy zamawiającego, inspektorzy końcowego odbiorcy i inspektorzy producenta.

Akceptowany był poziom kompetencji IWE lub IWI i VT2.

\section{Kwalifikacje technologii spawania}

Technologie spawania i technologii napraw były kwalifikowane zgodnie z przepisami DNV-OS-C401 [1]. Wg powyższych przepisów, jeśli przy naprawie usuwamy więcej niż 1/4 grubości materiału, należy kwalifikować technologię naprawy wykonując spawanie próbki, wycięcie spoiny i ponowne spawanie, tak żeby poddać spawaną próbkę takiemu samemu cyklowi cieplnemu, jak przy naprawie spoiny w konstrukcji. Wg zaleceń przepisów [1], temperaturę wstępnego podgrzania należy zwiększyć przy ponownym spawaniu o $50^{\circ} \mathrm{C}$.

Do celów projektu przyjęto zarówno wcześniej opracowane technologie, jak i technologie opracowane dla opisywanej konstrukcji. Stosowane procesy spawania: 138 i 136.

\section{Kontrola i badanie}

\section{Organizacja kontroli i badań}

Wykonawca przez czas realizacji projektu dysponował pracownikami kontroli w obszarze:

- pomiarów geometrycznych

- prac spawalniczych

- identyfikacji prac spawalniczych

- badań NDT: VT, MT i UT.

\section{Zakres kontroli}

\section{Kontrola przed spawaniem}

Kontrola przed spawaniem obejmowała:

\section{Spawacze}

Sprawdzenie uprawnień spawaczy do wykonywania danych złączy.

Złącza konstrukcji zostały podzielone na kilka kategorii w zależności od stopnia trudności. Spawacze w uzgodnieniu z inspektorem klienta byli dopuszczani do wykonywania właściwej kategorii złącza, zaczynając od złączy najprostszych. Jeśli rezultaty ich pracy były pozytywne - wadliwość złączy poszczególnych spawaczy była rejestrowana - przechodzili do kategorii wyższej. Jeżeli ilość wad spawalniczych była znacząca, byli przesuwani do prac prostszych, w skrajnym wypadku byli odsuwani od pracy przy tym projekcie.

Sprawdzenie znajomości WPS-ów i opis spoiny.

Spawacz przed przystąpieniem do pracy opisywał spoinę wpisując między innymi swój znak i nr WPS, wg którego pracował. Sprawdzający od razu widział, czy WPS został dobrany zgodnie z planem spawania. Nowo zatrudnieni spawacze, mimo instruktażu i pomimo dostępności na hali właściwej dokumentacji, nie zawsze dobierali właściwy WPS. Wiązało się to ze zmianą drutu spawalniczego i temperaturą wstępnego podgrzania elementów.

Sprawdzenie wyposażenia spawalniczego i pomiarowego: do pomiaru temperatury, pomiaru przepływu gazu osłonowego, przymiary do oceny kształtu i rozmiaru spoiny zgodnie z zaleceniami klienta.

Przygotowanie elementów

- zgodność montażu (wielkość szczeliny, ukosowanie) z dokumentacją,

- oczyszczenie miejsc spawanych z tłuszczu, rdzy i innych zanieczyszczeń,

- sposób podklejenia podkładki ceramicznej, jeśli była wymagana.

Tablica I. Poziom jakości dla spoin i zakres badań NDT

Table I. The quality level and scope of NDT

\begin{tabular}{|c|c|c|c|c|c|}
\hline \multirow{2}{*}{$\begin{array}{c}\text { Kategoria } \\
\text { złączy } \\
\text { wg OS-C401 }\end{array}$} & \multirow{2}{*}{$\begin{array}{l}\text { Poziom jakości } \\
\text { wg EN } 5817\end{array}$} & \multirow{2}{*}{ Rodzaj złączy } & \multicolumn{3}{|c|}{ Zakres badań NDT } \\
\hline & & & VT & MT/ PT & UT/ RT \\
\hline Kat I & $B^{*}$ & \multirow{2}{*}{ Złącza kątowe ze spoinami czołowymi } & $100 \%$ & $100 \%$ & $100 \%$ \\
\hline KAT II & C & & $100 \%$ & $20 \%$ & $20 \%$ \\
\hline
\end{tabular}




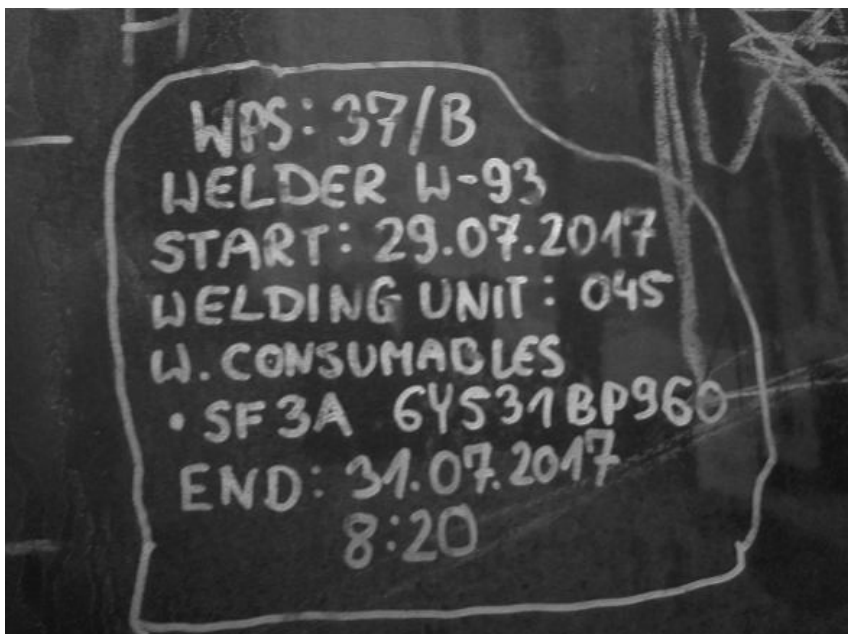

Rys. 4. Opis spoiny

Fig. 4. A welding joint description

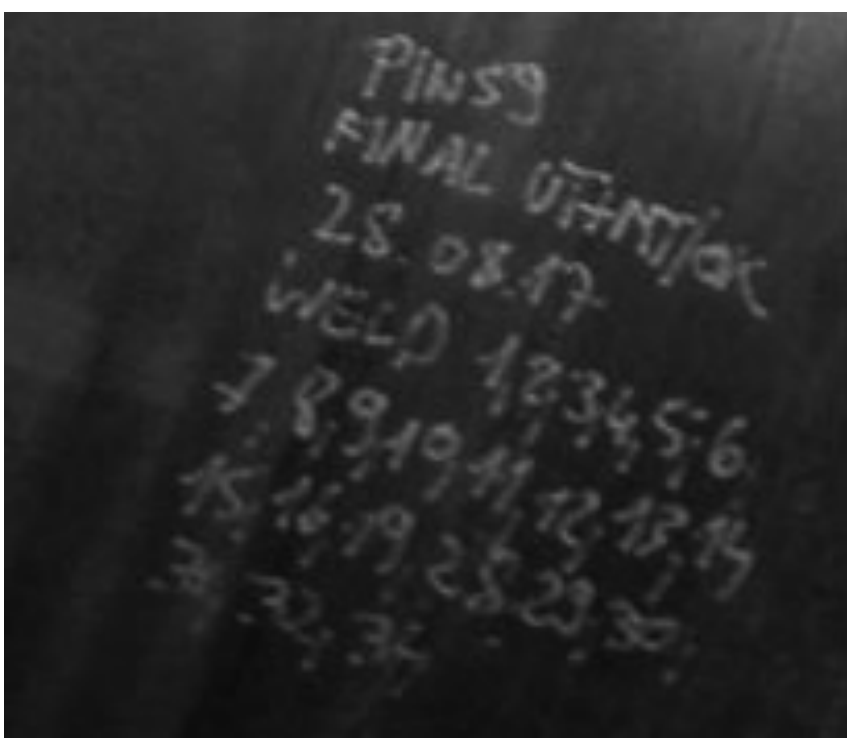

Rys. 5. Oznaczenie statusu NDT na konstrukcji

Fig. 5. Status of NDT

Materiał dodatkowy

- zgodność materiału dodatkowego z WPS, identyfikowalność materiałów,

Urządzenia spawalnicze i narzędzia

- stan urządzeń spawalniczych, stan uchwytu spawalniczego i dobór rozmiaru dyszy do prowadzonych prac,

- wyposażenie w stosowne narzędzia i urządzenia: do szlifowania, do podgrzewania.

Temperatura

- sposób podgrzewania elementów przed spawaniem: grzanie elektryczne lub gazowe i temperaturę wstępnego podgrzania.

Warunki spawania

- zapewnienie właściwych warunków spawania i dostępu; rusztowania, osłony, zabezpieczenie przed przeciągami, osłony termiczne dla spawaczy, oświetlenie.

\section{Kontrola w trakcie spawania}

\section{Parametry spawania}

Pomiary parametrów spawania: dla obliczenia energii liniowej, wielkości przepływu gazu osłonowego, temperatury wstępnego podgrzania i międzyściegowej.

WPQR-y do części złączy opracowano tylko dla jednej pozycji spawania. Zakres energii liniowej zgodnie z przepisami DNV [1] obliczany jest jako średnia wartość dla ściegów wykonanych $w$ trakcie testów +/- $25 \%$ (jest to mniejszy zakres od tego, który dopuszcza EN 15614-1 [6]).
W efekcie zakres energii podany w WPS był węższy, niż zakres energii w wykonanym złączu próbnym przy kwalifikowaniu technologii. Spoiny musiały być wykonane $w$ tak zdefiniowanym przedziale energii, co wymagało częstych pomiarów i korygowania parametrów. Z klientem uzgodniono, że zapisy z pomiaru parametrów spawania będą dołączane do dokumentacji zdawczej.

Stan oczyszczenia poszczególnych ściegów i kształt rowka po wycięciu grani

Złącza przygotowane na "K" spawano dwustronnie z podkładką okrągłą. Grań wycinano elektro-powietrznie tak, żeby usunąć warstwę przetopową. Kształt rowka spawalniczego sprawdzano przymiarem dobranym tak, żeby zapewnić właściwe wtopienie w materiał.

Po oszlifowaniu miejsca po żłobieniu, badano powierzchnię metodą magnetyczno-proszkową (MT). Jeśli wynik badania MT był pozytywny, złącze było dopuszczane do dalszego spawania.

\section{Kontrola po spawaniu}

Identyfikowalność spawania

Wymagany przez klienta opis spoin zawierał: znak spawacza, nr WPS, oznaczenie materiału dodatkowego (nazwa i nr wytopu), data i godzina zakończenia spawania, status NDT i nr spoiny.

$\underline{N D T}$

- badania wizualne (VT) w szczególności sprawdzenie kształtu i rozmiaru spoin,

- badania magnetyczno-proszkowe (MT),

- badania ultradźwiękowe (UT).

Badaniom wizualnym podlegała cała konstrukcja, oprócz spoin badany był stan powierzchni elementów. W szczególności sprawdzano usunięcie śladów po przyspawanych i usuniętych elementach technologicznych, śladów zajarzenia łuku i pozostałości po nieumiejętnym użyciu szlifierki.

\section{Zapisy z kontroli i badań}

Zapisy z kontroli i badań, jakie powstawały to:

- raporty z inspekcji procesu spawania,

- raporty z pomiaru parametrów spawania,

- dziennik spawania, w którym rejestrowano status spawania i badań i kto je wykonywał,

- raporty z NDT,

- raport pomiarowy.

\section{Analiza przypadków}

Kwalifikowanie technologii spawania. lle czasu trzeba przeznaczyć na badanie technologii?

Dla uzupetnienia posiadanych kwalifikowanych technologii spawania, przystąpiono do opracowania kolejnej technologii:

Metoda spawania: 138/136

Złącze ze spoiną czołową

Materiał podstawowy: S355 J2 +N, grubość $40 \mathrm{~mm}$

Parametry materiału $\mathrm{wg}$ świadectwa odbioru 3.1 :

Średnia praca łamania: $144 \mathrm{~J}$ w temperaturze $-20^{\circ} \mathrm{C}$

Równoważnik węgla: $\mathrm{C}_{\text {eq }}=0,45$

Po wykonaniu złącza próbnego i przeprowadzeniu badań nieniszczących, złącza z wynikiem pozytywnym poddawano badaniom mechanicznym.

Przy badaniu udarności uzyskano następujące wartości średnie:

- w spoinie: $42 \mathrm{~J}$

- w linii wtopienia: $125 \mathrm{~J}$

- linia wtopienia $+2 \mathrm{~mm}: 11 \mathrm{~J}$

- linia wtopienia +5 mm: $9 \mathrm{~J}$ 
Z arkusza blachy przeznaczonego do testów wycięto próbki i wykonano badanie udarności.

Średni uzyskany wynik: $10 \mathrm{~J} \mathrm{w}$ temperaturze $-20^{\circ} \mathrm{C}$. Wniosek 1:

Spawanie nie zawsze pogarsza właściwości materiału. Wniosek 2:

Na kwalifikowanie technologii trzeba przeznaczyć na ogół więcej czasu, niż nam się wydaje.

Wniosek 3:

Do informacji zawartych w świadectwach materiałów podchodzić należy z ograniczonym zaufaniem.

\section{Szkolenie i dokumentacja dla spawaczy}

Spawacze sprawdzeni i zakwalifikowani do pracy, przechodzili szkolenie, byli zapoznawani z WPS-ami i dokumentacją, gdzie do każdej spoiny był przypisany WPS. Dokumentacja taka była dostępna w miejscu prowadzenia prac. Mimo to, jak się okazało, nowi spawacze wymagali szczegółowej kontroli i sprawdzenia znajomości dokumentacji i umiejętności czytania WPS.
Zdarzało się, że do wykonywanej spoiny błędnie odczytywali nr WPS, w konsekwencji pobierali niewłaściwy drut. Mieli też problem z właściwym określeniem temperatury wstępnego podgrzania. Niektóre WPS-y zawierały informacje o temperaturze wstępnego podgrzania w funkcji grubości materiału. Drobny element dostawiony grubości 15 $\div 20 \mathrm{~mm}$ byli w stanie zmierzyć. Grubość tą interpretowali jako wielkość parametru z WPS. Grubość ścianki rury, do którego element był spawany, a wynosiła ona $75 \mathrm{~mm}$, był poza ich polem obserwacji i interpretacji. Każdy nowy spawacz wymagał przed rozpoczęciem pracy sprawdzenia czy wie, który WPS powinien zastosować i czy prawidłowo go odczyta.

Wniosek 1: im mniej dokumentów dostanie pracownik tym mniejsze prawdopodobieństwo, że się w tym pogubi.

Wniosek 2: instrukcje, w tym WPS-y, powinny być możliwie proste i jednoznaczne, bez pola do interpretacji.

Wniosek 3: przy tak złożonym projekcie, pomoc i kontrola ze strony nadzoru (pracowników kontroli) jest niezbędna do wdrożenia pracowników i zapewnienia prawidłowego procesu spawania.

\section{Wnioski}

- Wykonanie odpowiedzialnych konstrukcji wymaga starannego przygotowania od strony organizacyjnej, technologicznej, sprzętowej i kadrowej.

- Przygotowanie takie - czasochłonne i kosztowne - obniża koszty późniejszych działań, szczególnie, gdy pojawią się "nieprzewidziane zdarzenia".

- W obecnych czasach najtrudniejsze wydaje się skompletowanie dodatkowych zasobów ludzkich (spawaczy, nadzoru, personelu kontroli i badań) i stanowi to istotną barierę przy wzroście produkcji, szczególnie, jeśli wiąże się to ze wzrostem wymagań jakościowych dla wykonywanych konstrukcji.

- Właściwie prowadzona kontrola prac spawalniczych pozwala na wczesne wychwycenie błędów w produkcji. W efekcie pozwala na wprowadzenie korekt i uzyskanie wyrobu spełniającego wymagania klienta i często znaczące obniżenie kosztów.

- Kontrola prac spawalniczych jest niezbędnym elementem zapewnienia właściwego poziomu jakości konstrukcji spawanych.

\section{Literatura}

[1] Przepisy DNV: Offshore Standard DNV-OS-C401

[2] EN ISO 3834-2: Wymagania jakości dotyczące spawania materiałów metalowych - Część 2: Pełne wymagania jakości

[3] Saperski J.: Wpływ wprowadzenia PN-EN 1090 na spawalnictwo w małych wytwórniach konstrukcji spawanych, Materiały XX Naukowo-Technicznej: Konferencji „Postęp, innowacje i wymagania jakościowe procesów spajania", Międzyzdroje 27-29.05.2014

[4] Saperski J.: Wymagania jakościowe konstrukcji offshore; Materiały XIV Naukowo-Technicznej Konferencji: „Postęp, innowacje i wymagania jakościowe procesów Spajania", Międzyzdroje 27-29.05.2008
[5] Saperski M.: Procedura kwalifikowania technologii spawania konstrukcji offshore według przepisów Det Norske Veritas - Biuletyn Instytutu Spawalnictwa $\mathrm{nr} 6 / 2010$.

[6] EN ISO 15614-1: Specyfikacja i kwalifikowanie technologii spawania metali - Badanie technologii spawania - Część 1: Spawanie łukowe i gazowe stali oraz spawanie łukowe niklu i stopów niklu. 